\title{
HUBUNGAN ANTARA ORGANIZATIONAL CHARACTERISTICS, ENVIRONMENTAL CHARACTERISTICS DAN ENTREPENEURIAL ORIENTATION TERHADAP INOVASI TERBUKA SERTA KINERJA INOVASI (Survei pada UKM Provinsi Jawa Timur)
}

\author{
Ari Irawan \\ Fakultas Ilmu Administrasi, Universitas Brawijaya, Malang, Indonesia \\ email: ari.irawan@ub.ac.id
}

\begin{abstract}
This study was conducted to determine the relationship between organizational characteristics, environmental characteristics and entrepreneurial orientation of startup companies in East Java to open innovation. The unit of analysis is startup owner or technopreneur owners in Malang City, Surabaya City and Kediri City as the research sample area. The number of respondents obtained was 102 business owners who use technology in their business practices. This type of research is explanatory quantitative research by describing the relationship between variables using the online version of the GSCA (Generalized Structured Component Analysis) software to analyze. The results of the study by comparing the values of $t$, showed that the three hypotheses were not supported by this study while the remaining 4 (four) hypotheses were supported.
\end{abstract}

Keywords: entrepeneurship, technopreneur, open innovation, innovation performance

\begin{abstract}
ABSTRAK
Penelitian ini dilakukan untuk mengetahui hubungan antara organizational characteristics, environment characteristics dan entrepeneurial orientation pada perusahaan startup di Jawa Timur terhadap inovasi terbuka. Unit analisis pada pemilik perusahaan startup atau technopreneur di Kota Malang, Kota Surabaya dan Kota Kediri sebagai wilayah yang dijadikan sampel penelitian. Jumlah responden yang didapatkan berjumlah 102 pemilik perusahaan yang menggunakan teknologi dalam praktek usahanya. Jenis penelitian ini adalah penelitian kuantitatif eksplanatori dengan menggambarkan hubungan antar variabel menggunakan software GSCA (Generalized Structured Component Analysis) versi online untuk menganalisis. Hasil penelitian dengan membandingkan antara nilai t, menunjukkan bahwa tiga hipotesis tidak didukung penelitian ini sedangkan sisanya 4 (empat) hipotesis di dukung.
\end{abstract}

Kata Kunci: Kewirausahaan, technopreneur, open innovation, innovation performance 


\section{PENDAHULUAN}

Teknologi Informasi di dunia mengalami perkembangan yang luar biasa, tidak terkecuali di Indonesia. Perkembangan ini seiring dengan penemuan dan pengembangan Ilmu Pengetahuan dalam bidang Informasi dan Komunikasi. Sebagai negara berkembang, Indonesia juga beradaptasi dengan teknologi, salah satunya dengan teknologi internet. Seiring perkembangan internet di Indonesia yang semakin murah dan mudah, kian banyak orang menggunakan media ini untuk berbagai hal, salah satunya berwirausaha. Kini banyak entrepreneur muda yang menjalankan usahanya berbasis internet atau disebut Technopreneur.

Technopreneur adalah bagian dari kewirausahaan yang akan memainkan peranan strategis bagi perkembangan ekonomi Indonesia di masa mendatang. Technopreneur punya posisi strategis saat ini untuk perputaran dan percepatan perekonomian Indonesia. Para technopreneur yang umumnya didominasi anak-anak muda banyak merintis bisnis atau perusahaannya berbasis internet sehingga disebut startup company. Startup company juga perlu memanfatkan teknologi informasi untuk membangun jaringan yang mendukung aliran gagasan dan informasi baik ke dalam dan keluar dari batas-batas organisasi. Chesbrough (2003) berpendapat bahwa inovasi terbuka sangat penting untuk menciptakan keuntungan dari pemanfaatan teknologi.

Penelitian ini memfokuskan objek penelitian pada technopreneurship sebagai bagian dari perkembangan terbaru dari kewirausahaan dengan berbasis pada teknologi. Selain itu, subjek penelitian ini adalah penerapan paradigma baru dalam inovasi yaitu inovasi terbuka pada technopreneur yang termasuk dalam Usaha Kecil dan Menengah (UKM) di Provinsi Jawa Timur. Meneliti praktik inovasi terbuka pada UKM khususnya di bidang technopreneurship merupakan hal yang penting untuk dilakukan dalam rangka meningkatkan kinerja technopreneur sebagai sektor industri baru.

\section{KAJIAN PUSTAKA}

\section{Kewirausahaan (Entrepreneurship)}

Drucker (1985) mengartikan

kewirausahaan sebagai semangat, kemampuan, sikap dan perilaku individu dalam menangani usaha (kegiatan) yang mengarah pada upaya mencari, menciptakan, menerapkan cara kerja, teknologi, dan produk baru dengan meningkatkan efisiensi dalam rangka memberikan pelayanan yang lebih baik dan atau memperoleh keuntungan yang lebih besar.

\section{Inovasi (Innovation)}

West (2000) menyatakan bahwa inovasi merupakan pengenalan dan penerapan ide, proses, produk, atau prosedur baru yang lebih baik secara sengaja kepada pekerjaan, tim kerja, atau organisasi tersebut. Dalam hal ini inovasi merupakan segala bentuk produk baru yang lebih baik atau cara baru yang lebih baik yang diperkenalkan oleh individu,kelompok atau organisasi dan yang mempengaruhi pekerjaan, individu, kelompok atau organisasi.

\section{Technopreneurship}

Objek penelitian ini adalah technopreneur yang merupakan bentuk pengembangan bisnis UKM berbasis teknologi. Mayoritas pengusaha yang bergerak sebagai technopreneur memulai bisnisnya dari UKM. Terlebih lagi jumlah UKM di Indonesia sangat banyak, sehingga sentuhan teknologi akan dapat membuat UKM menjadi lebih maju dan lebih lanjut diharapkan dapat membantu mendorong kinerja perekonomian nasional. Kewirausahaan teknologi atau technopreneurship dapat diartikan sebagai kewirausahaan yang aktivitas usahanya berbasis pada teknologi (BPPT, 2010). Sedangkan pewirausaha teknologi (technopreneur) adalah pelaku wirausaha berbasis teknologi

\section{Karakter-Karakter (Organizational Characteristics)}

Karakter-Karakter Organisasional merupakan struktur dan peralatan infrastruktur dalam organisasi yang berkaitan dengan persiapan untuk penerapan suatu strategi manajemen (Li, 2002). Karakter-karakter organisasional ini dibedakan menjadi 2 (dua) kelompok besar, yaitu, 1) infrastruktur teknologi, merupakan peralatan dan sistem yang menjadi instrumen dalam kegiatan komunikasi dan manajemen lintas organisasi. Dalam penelitian ini karakter-karakter organisasional terkait infrastuktur teknologi diukur dengan sistem pendukung komunikasi, sistem manajemen database; sistem kolaborasi; 2) infrastruktur organisasional, merupakan faktor-faktor yang mempersiapkan perusahaan untuk siap berkolaborasi berkaitan dengan seluruh sistem sosial, struktur, proses 
pengembangan, mekanisme komunikasi, jaringan sosial, imbalan dan korespondensi dengan strategi bisnis dan strategi operasi.

\section{Karakter-Karakter \\ Lingkungan (Environemental Characteristics) \\ Karakter-karakter \\ lingkungan}

merupakan faktor lingkungan yang mempengaruhi tingkat pelaksanaan suatu strategi perusahaan dimana terdapat tiga faktor utama yang sangat berpengaruh meliputi ketidakpastian lingkungan dalam bisnis, tekanan daya saing untuk melakukan implementasi dan kesiapan rekan bisnis untuk berkolaborasi (Li, 2002).

\section{Orientasi Wirausaha (Entrepreneur Orientation)}

Lumpkin and Dess

mendefinisikan Orientasi wirausaha sebagai penggambaran bagaimana new entry dilaksanakan (Lumpkin and Dess, 1996). Orientasi wirausaha digambarkan oleh proses praktek dan aktivitas pembuatan keputusan yang mendorong new entry. Lebih lanjut, Covin and Lumpkin (2011) menyatakan bahwa orinetasi kewirausahaan merupakan proses dimana individu dalam sebuah perusahaan yang didirikan mengejar peluang kewirausahaan untuk berinovasi tanpa memperhatikan tingkat dan sifat saat sumber daya yang tersedia. ENTREPENEURial ORIENTATION adalah upaya untuk memperpanjang keunggulan kompetitif organisasi. Selain itu Moreno and Casillas (2008) berpendapat bahwa orintasi kewirausahaan adalah pengambilan keputusan organisasi dengan kecenderungan mendukung kegiatan kewirausahaan.

\section{Inovasi Terbuka (Open Innovation)}

Chesbrough (2003), mengungkapkan bahwa di era pengetahuan yang melimpah, perusahaan perlu untuk memanfaatkan ide-ide eksternal dan memanfaatkan Penelitian dan Pengembangan di luar operasi mereka. Paradigma ini berbeda dari yang lama dalam inovasi tertutup (closed innovation). Inovasi tertutup memiliki pandangan bahwa inovasi yang sukses membutuhkan kontrol. Perusahaan harus menghasilkan ide sendiri dan mengembangkan, membangun, memasarkan, mendistribusikan, memberikan layanan, mengelola keuangan, dan mendukung perusahaan mereka sendiri. Inovasi tertutup, mendorong perusahaan untuk menjadi sangat mandiri karena seseorang tidak dapat memastikan kualitas, ketersediaan dan kemampuan ide orang lain (Chesbrough, 2003).

Sebaliknya, inovasi terbuka (open innovation) sebagai paradigma baru, dimana Chesbrough (2003) mengasumsikan bahwa inovasi terbuka sebagai "paradigm that assumes that firms can and should use external as well as internal ideas, and internal and external paths to market, as they look to advance their technology". Berdasarkan pendapat tersebut dapat diartikan bahwa open innovation adalah sebuag paradigma yang berasumsi bahwa perusahaan bisa dan seharusnya menggunakan beberapa ide daru dalam dan luar perusahaan ke pasar untuk memajukan teknologi perusahaan.

\section{Penerapan Inovasi Terbuka pada Usaha Kecil dan Menengah}

Berbagai literatur tentang inovasi terbuka menunjukkan bahwa dalam satu dekade terakhir pergeseran luar biasa dalam bisnis dimana telah terjadi pertumbuhan dalam penggunaan kemitraan eksternal dan meningkatkan interaksi antara aktor-aktor yang berbeda menjadi fokus utama. Sebuah perusahaan dapat berkolaborasi dengan pemasok, klien, pesaing, organisasi profesi, perguruan tinggi dan laboratorium penelitian. Terdapat berbagai bentuk kolaborasi inovasi terbuka termasuk joint venture, hibah dan beasiswa, jaringan inovasi, inovasi kolaboratif.

Dalam Usaha Kecil dan Menengah (UKM), proyek kolaborasi dalam inovasi terbuka tidak selalu mengambil bentuk tertentu dan terdokumentasi (seperti perjanjian penelitian dan pengembangan serta program penjualan/ pembelian lisensi), sehingga memberikan keengganan UKM untuk berkolaborasi dengan pihak eksternal dan membuka strategi mereka terhadap pengetahuan eksternal (Coras and Tantau, 2013).

\section{Kinerja Inovasi (Innovation Performance)}

Secara khusus, innovation performance pada produk dan pasar adalah kinerja inovasi antar dua hal yang saling berkaitan. kedua hal di atas berfokus eksternal dan berbasis pasar, sedangkan kinerja inovasi perilaku dan proses berfokus internal. Kinerja inovasi strategis menyoroti kemampuan sebuah organisasi untuk mengidentifikasi peluang eksternal secara tepat waktu sesuai dengan peluang diluar kemampuan internal untuk 
memberikan produk inovatif dan mencari pasar atau sektor baru.

\section{Hipotesis Penelitian}

Dari dasar kajian teori di atas dalam penelitian ini merumuskan hipotesis dan hubungan antar variabel sebagai berikut:

Stuki and Finger (2009) mengembangkan model faktor yang mempengaruhi inovasi terbuka, dimana terdiri dari perspektif ektsternal industri dan perusahaan serta faktor internal perusahaan. Dimana faktor internal perusahaan terdiri dari strategi dan tujuan inovasi, manajemen inovasi serta karakteristik organisasi. Lebih lanjut, Bingham (1976) (dalam Fimm, 2011) menyatakan dalam model adopsi inovasi pada pemerintah daerah bahwa Organizational Characteristics dan Environment Characteristics berpengaruh signifikan terhadap adopsi inovasi.

\section{H1 Organizational Characteristics berpengaruh signifikan terhadap Inovasi Terbuka}

Abulrub and Lee (2012) yang melakukan penelitian pada 209 UKM dan 300 perusahaan besar di Korea Selatan menemukan bahwa faktor lingkungan berpengaruh signifikan dalam penerapan inovasi terbuka. Hal ini secara empiris mendukung teori yang dikembangkan Bingham (1976) (dalam Fimm, 2011) yang dinyatakan dalam model adopsi inovasi pada pemerintah daerah bahwa Organizational Characteristics dan Environment Characteristics berpengaruh signifikan terhadap adopsi inovasi.

\section{H2 Environmental Characteristics berpengaruh signifikan terhadap Inovasi Terbuka}

Penelitian studi kasus yang dilakukan Lakovleva (2013) menunjukkan hasil yang memperkuat hipotesis ini secara teoritis. Hasil penelitian pada UKM yang beroperasi pada sektor pertambangan minyak di Norwegia tersebut menemukan bahwa ENTREPENEURial ORIENTATION yang terdiri dari keinovasian, mengambil resiko dan keproaktifan mempengaruhi pelaksaan inovasi terbuka terutama pada perusahaan UKM yang bergerak pada sektor pertambangan minyak.

\section{H3 Entrepeneurial Orientation berpengaruh} signifikan terhadap Inovasi Terbuka

Dalam penelitian yang dilakukan Prajogo and Ahmed (2006) diperoleh hasil bahwa integrasi antara aspek kepemimpinan dan sumberdaya manusia serta teknologi dalam karakteristik organisasi akan berpengaruh terhadap kinerja inovasi dengan menggunakan permodelan stimulus inovasi.

Selain itu, dalam beberapa penelitian empiris menunjukkan bahwa karakter strategi internal perusahaan yang menjadi bagian dari teknologi secara signifikan berpengaruh pada kinerja inovasi (Katila, 2002 dan Katila and Ahuja, 2002).

\section{H4 Organizational Characteristics berpengaruh signifikan terhadap Kinerja Inovasi}

Prajogo and Sohal (2001) mengungkapkan bahwa lingkungan bisnis, strategi organisasional dan budaya organisasi berdampak pada praktek Total Quality Management yang menentukan kualitas atau kinerja inovasi.

\section{Hasil penelitian Frishamman and Horte} (2005) mununjukkan bahwa lingkungan berpengaruh positif terhadap kinerja inovasi dengan menggunakan analisis regresi berganda. Selain itu, hasil penelitian Hung (2007) menyatakan bahwa terdapat pengaruh signifikan antara Environment Characteristics dan kinerja inovasi.

\section{H5 Environment Characteristics berpengaruh signifikan terhadap Kinerja Inovasi}

Lumpkin and Dess (2001) dalam model ENTREPENEURial ORIENTATION yang dikembangkannya mengungkapkan bahwa orientasi perusahaan yang terdiri dari kebebasan, inovasi, resiko, proaktif, keagresifan bersaing berpengaruh terhadap kinerja perusahaan setelah melakukan inovasi dengan faktor-faktor perusahaan dan faktorfaktor organisasional sebagai variabel moderating.

\section{H6 Entrepeneurial Orientation berpengaruh signifikan terhadap Kinerja Inovasi}

Penelitian Inauen and Wicki (2011) terhadap 141 manajer Litbang perusahaan yang terdaftar di bursa efek di Jerman, Switzerland dan Austria menemukan bahwa strategi 
manajemen dengan menggunakan open outside-in innovation dalam proses inovasi berpengaruh signifikan terhadap kinerja inovasi perusahaan. Lebih lanjut, Parida et al (2012) melakukan penelitian pada 252 perusahaan UKM high-tech yang melakukan inovasi terbuka. Hasil penelitian tersebut menemukan bahwa inovasi terbuka berpengaruh signifikan terhadap peningkatan kinerja inovasi. Hasil penelitian tersebut didukung oleh penelitian Huang (2011); Lauren and Salter (2006); Herstad et al (2008); Gil (2011) dan Mazzola et al (2012) yang juga menemukan bahwa penerapan inovasi terbuka akan berpengaruh terhadap peningkatan kinerja inovasi perusahaan.

\section{H7 Inovasi Terbuka berpengaruh signifikan terhadap Kinerja Inovasi}

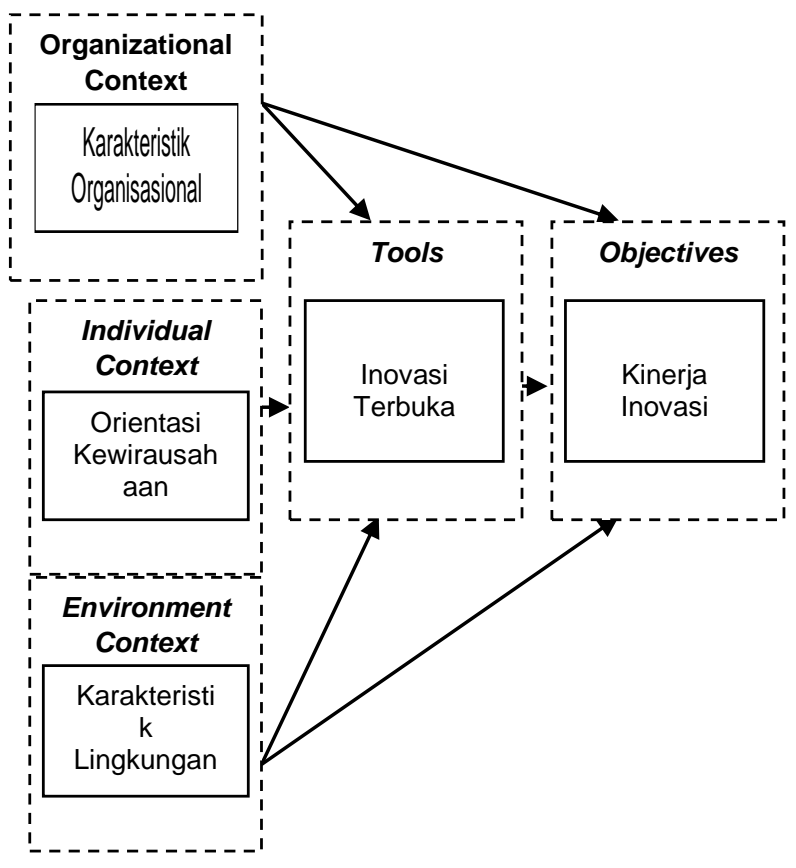

\section{Gambar 1 Kerangka Pemikiran}

\section{METODE PENELITIAN}

Jenis penelitian ini adalah penelitian eksplanatori dengan pendekatan kuantitatif, serta menggunakan survei sebagai sarana untuk memperoleh data dari responden. Lokasi penelitian di Provinsi Jawa Timur dengan unit analisis perusahaan technopreneur atau perusahaan startup. Populasi penelitian ini adalah keseluruhan pemilik UKM baru di provinsi Jawa Timur pada tahun 2013. Dalam penelitian ini populasi tidak diketahui jumlahnya karena tidak tersedianya data resmi mengenai jumlah technopreneur di provinsi Jawa Timur. Sampel penelitian ini berjumlah 102 orang yang tersebar di Kota Malang, Kota Surabaya dan Kota Kediri.

Analisis data yang digunakan untuk membuktikan hipotesis yang diajukan dalam penelitian ini menggunakan GSCA (Generalized Structured Component Analysis) dengan software GSCA secara online. Model dimaksud di dalam Generalized Structured Component Analysis dipergunakan untuk menentukan sifat indikator dari setiap variabel laten, refleksif atau formatif (Solimun, 2012). Model pengukuran pada penelitian ini akan menjadi seperti pada Gambar 2.

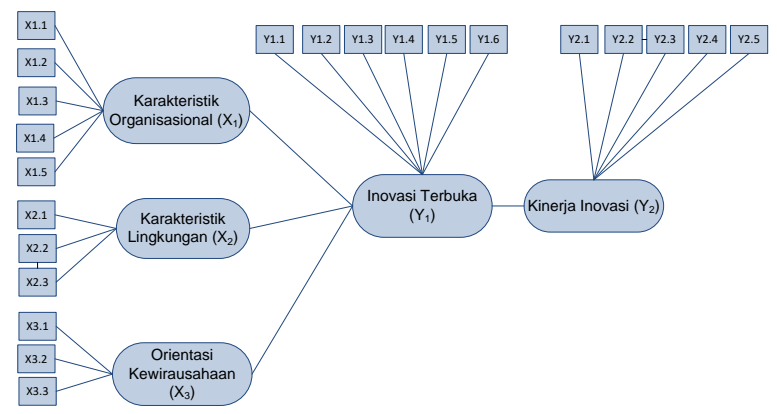

Gambar 2 Model Pengukuran

\section{HASIL DAN PEMBAHASAN}

Hasil pengujian hipotesis diperoleh dengan perbangingan t-statsitik dan t-tabel, jika nilai t-statistik lebih besar dari t-tabel maka hubungan antar konstruk signifikan dan dapat dianalisis lebih lanjut. Dalam penelitian ini jumlah data yang digunakan adalah 102, jumlah konstruk adalah 5 (lima) yang terdiri dari konstruk Organizational Characteristics (X1) Environment Characteristics (X2), Entrepeneurial Orientation (X3) Inovasi Terbuka (Y1) dan Kinerja Inovasi (Y2). 


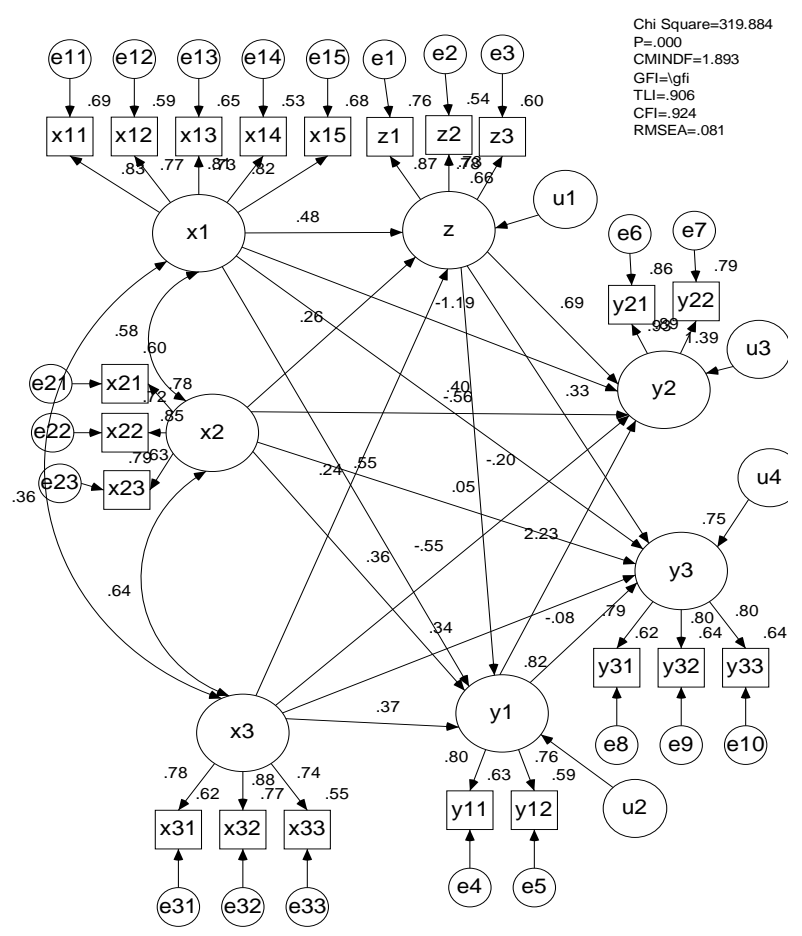

\section{Gambar 3 Model Hasil Pengujian Hipotesis}

Hasil uji hipotesis dalam penelitian ini menggunakan $\alpha$ pada level 5\%, dengan rumus $\mathrm{df}=(\mathrm{n}-\mathrm{k}-1)$ maka didapat nilai df adalah sebesar 132. Dari gambar 3 di atas dapat disimpulkan hasil pengujian hipotesis sebagai berikut:

\section{H1 Organizational Characteristics} berpengaruh signifikan terhadap Inovasi Terbuka, adalah tidak signifikan sehingga $\mathbf{H 1}$ di tolak.

Hasil penelitian ini kontradiktif terhadap hasil penelitian Mortara and Minshall (2011) yang menyimpulkan bahwa karakteristik organisasi disesuaikan dengan kebutuhan bisnis yang diperlukan untuk melakukan inovasi terbuka serta terhadap penelitian terdahulu yang dilakukan Mel et al (2009) yang menemukan bahwa karakteristik perusahaan berpengaruh signifikan terhadap inovasi pada UKM. Perbedaan hasil penelitian ini dapat dikarenakan berdasarkan hasil penelitian ini ditemukan bahwa struktur organisasi dan infrastruktur teknologi dalam Karakteristik Organisasi pada perusahaan startup masih sederhana di mana sistem pendukung komunikasi, sistem manajemen data base, sistem kolaboratif, kolaborasi budaya organisasi dan partisipasi manajemen belum terbentuk dengan optimal dan berdasarkan deskripsi responden ditemukan bahwa sebanyak $49 \%$ responden merupakan perusahaan startup dengan usia perusahaan yang masih baru berdiri kurang dari 1 (satu) tahun sehingga hal tersebut menjadikan karakteristik organisasi perusahaan startup belum sepenuhnya mampu mendorong manajemen untuk menerapkan inovasi terbuka dalam perusahaan.

H2 Environment Characteristics berpengaruh signifikan terhadap Inovasi Terbuka, adalah tidak signifikan sehingga $\mathbf{H 2}$ di tolak.

Hasil penelitian ini kontradiktif dengan hasil penelitian yang dilakukan Abulrub and Lee (2012) yang melakukan penelitian pada 209 UKM dan 300 perusahaan besar di Korea Selatan di mana hasil penelitian menemukan bahwa faktor lingkungan berpengaruh signifikan dalam penerapan inovasi terbuka. Berdasarkan hasil penelitian ini ditemukan bahwa Environment Characteristics tidak berpengaruh signifikan terhadap Inovasi Terbuka di mana hal ini menjadi temuan dalam penelitian ini. Walaupun ketidakpastian lingkungan dalam hal memahami selera konsumen pada perusahaan startup tinggi namun tekanan daya saing dalam industri masih rendah dan kesigapan rekan bisnis cenderung belum dibutuhkan, sehingga dengan bentuk Environment Characteristics tersebut maka perusahaan startup untuk bertahan dalam persaingan model inovasi yang diterapkan masih cukup dengan menggunakan paradigma inovasi tertutup.

H3 Entrepeneurial Orientation berpengaruh signifikan terhadap Inovasi Terbuka, adalah signifikan sehingga $\mathbf{H 3}$ diterima.

Penelitian ini mendukung hasil penelitian studi kasus yang dilakukan Lakovleva (2013) yang menemukan bahwa Entrepeneurial Orientation yang terdiri dari keinovasian, mengambil resiko dan keproaktifan mempengaruhi pelaksaan inovasi terbuka terutama pada perusahaan UKM yang bergerak pada sektor pertambangan minyak dan penelitian $\mathrm{Ju}$ et al (2013) yang menemukan bahwa terdapat pengaruh signifikan antara inovasi terbuka, Entrepeneurial Orientation dan kinerja perusahaan. Hasil uji hipotesis menunjukkan bahwa Entrepeneurial Orientation berpengaruh signifikan terhadap Inovasi Terbuka. Hal ini menunjukkan bahwa perusahaan startup telah menerapkan keinovasian, mengambil resiko dan 
keproaktifan dalam bersaing di pasar sehingga dengan bentuk Entrepeneurial Orientation tersebut maka mempengaruhi perusahaan untuk menerapkan inovasi terbuka. Arah hubungan pengaruh Entrepeneurial Orientation dan inovasi terbuka adalah positif. Hal ini menunjukkan bahwa semakin tinggi penerapan orinetasi kewirausahaan dalam perusahaan maka akan semakin meningkatkan dorongan manajemen dalam menerapkan inovasi terbuka.

H4 Organizational Characteristics berpengaruh signifikan terhadap Kinerja Inovasi, adalah signifikan sehingga $\mathbf{H 4}$ ditolak.

Hasil penelitian ini bertentangan atau kontradiktif dengan penelitian yang dilakukan dilakukan Prajogo and Ahmed (2006) yang memperoleh hasil bahwa integrasi antara aspek kepemimpinan dan sumberdaya manusia serta teknologi dalam karakteristik organisasi akan berpengaruh terhadap kinerja inovasi dengan menggunakan permodelan stimulus inovasi serta hasil penelitian lainnya seperti Katila (2002) dan Katila and Ahuja (2002) yang menemukan terdapat pengaruh antara Organizational Characteristics dan kinerja inovasi. Hasil uji hipotesis menunjukkan bahwa Organizational Characteristics berpengaruh tidak signifikan terhadap Kinerja Inovasi dimana hal ini menjadi temuan dalam penelitian ini. Perbedaan hasil penelitian ini dapat dikarenakan berdasarkan hasil penelitian ini ditemukan bahwa Karakteristik Organisasi pada perusahaan startup masih sederhana di mana sistem pendukung komunikasi, sistem manajemen data base, sistem kolaboratif, kolaborasi budaya organisasi dan partisipasi manajemen belum terbentuk dengan optimal dan berdasarkan deskripsi responden ditemukan bahwa sebanyak $49 \%$ responden merupakan perusahaan startup dengan usia perusahaan yang masih baru berdiri kurang dari 1 (satu) tahun sehingga hal tersebut menjadikan karakteristik organisasi perusahaan startup belum sepenuhnya mampu menciptakan kinerja inovasi.

H5 Environment Characteristics berpengaruh signifikan terhadap Kinerja Inovasi, adalah signifikan sehingga $\mathbf{H 5}$ diterima.

Hasil pengujian hipotesis ini mendukung hasil penelitian Frishamman and Horte (2005) yang menunjukkan bahwa lingkungan berpengaruh positif terhadap kinerja inovasi serta mendukung hasil penelitian Hung (2007) menyatakan bahwa terdapat pengaruh signifikan antara Environment Characteristics dan kinerja inovasi. Berdasarkan hasil penelitian ini ditemukan bahwa Environment Characteristics berpengaruh signifikan terhadap Kinerja Inovasi. Hal ini dapat di karenakan walaupun ketidakpastian lingkungan dalam hal memahami selera konsumen pada perusahaan startup tinggi namun tekanan daya saing dalam industri masih reandah dan kesigapan rekan bisnis cenderung belum dibutuhkan, sehingga dengan bentuk Environment Characteristics perusahaan startup tersebut maka perusahaan dalam melakukan inovasi telah mampu menghasilkan kinerja inovasi. Arah hubungan pengaruh Environment Characteristics dan kinerja inovasi adalah positif. Hal ini mengindikasikan bahwa semakin banyak pengaruh ekternal dalam pembentukan Environment Characteristics perusahaan startup maka akan semakin meningkatkan kemampuan perusahaan dalam hal kinerja inovasi.

H6 Entrepeneurial Orientation berpengaruh signifikan terhadap Kinerja Inovasi, adalah signifikan sehingga H6 diterima.

Hasil pengujian hipotesis ini mendukung hasil penelitian Madhoushi (2011) pada 164 UKM di Iran yang menemukan bahwa manajemen pengetahuan dan Entrepeneurial Orientation berpengaruh signifikan terhadap kinerja inovasi. Berdasarkan hasil uji hipotesis ditemukan bahwa Entrepeneurial Orientation berpengaruh signifikan terhadap Kinerja Inovasi. Hal ini dapat dikarenakan perusahaan melakukan keinovasian, pengambilan resiko dan keproaktifan dalam persaingan industri membentuk Entrepeneurial Orientation dalam perusahaan sehingga perusahaan cenderung untuk mendukung kegiatan kewirausahaan di mana hal tersebut pada akhirnya akan meningkatkan kinerja inovasi di dalam perusahaan. Arah hubungan pengaruh Entrepeneurial Orientation dan Kinerja Inovasi adalah positif di mana hal tersebut mengindikasikan bahwa semakin meningkatnya proses praktik dan aktivitas orinetasi kewirausahaan dalam perusahaan maka akan semakin meningkatkan kinerja inovasi perusahaan.

H7 Inovasi Terbuka berpengaruh signifikan terhadap Kinerja Inovasi, adalah signifikan sehingga $\mathbf{H 7}$ diterima. 
Hasil pelitian ini mendukung hasil penelitian empiris yang dilakukan Inauen and Wicki (2011) yang menemukan bahwa strategi manajemen dengan menggunakan open outside-in innovation dalam proses inovasi berpengaruh signifikan terhadap kinerja inovasi perusahaan. Selain itu, penelitian ini juga mendukung hasil penelitian Parida et al (2012) melakukan penelitian pada 252 perusahaan UKM high-tech yang melakukan inovasi terbuka. Hasil penelitian tersebut menemukan bahwa inovasi terbuka berpengaruh signifikan terhadap peningkatan kinerja inovasi. Hasil penelitian ini juga mendukung hasil penelitian Huang (2011); Lauren and Salter (2006); Herstad et al (2008); Gil (2011) dan Mazzola et al (2012) yang juga menemukan bahwa penerapan inovasi terbuka akan berpengaruh terhadap peningkatan kinerja inovasi perusahaan.

Berdasarkan hasil penelitian ditemukan bahwa Inovasi Terbuka berpengaruh signifikan terhadap Kinerja Inovasi. Perbedaan hasil penelitian ini dengan penelitian sebelumnya dapat dikarenakan perusahaan startup merupakan perusahaan yang bersinggungan dengan teknologi informasi dan internet sehingga penggunaan modal ventura, lisensi kekayaan intelektual, keterlibatan karyawan, keterlibatan pelanggan, jaringan ekternal dan outsourching litbang dalam menerapkan dan mengembangkan dan melindungi ide-ide inovatifnya sangat diutamakan oleha karena itu bentuk inovasi dengan menggunakan inovasi terbuka sangat cocok digunakan dalam perusahaan startup dalam meningkatkan keunggulan kompetitifnya dalam hal kinerja inovasi. Arah hubungan pengaruh Inovasi Terbuka dan Kinerja Inovasi adala positif di mana hal ini mengindikasikan bahwa semakin baik penerapan inovasi terbuka yang dilakukan oleh manajemen maka akan semakin meningkatkan kinerja inovasi pada perusahaan startup.

\section{KESIMPULAN DAN SARAN Kesimpulan}

Hasil analisis penelitian baik secara keseluruhan serta pengujian beberapa teori dalam model penelitian, kesimpulan yang bisa di ambil dari penelitian ini antara lain: Walaupun perusahaan startup telah menerapkan system pendukung komunikasi, system manajemen database, system kolaboratif, kolaborasi budaya organisasi dan partisipasi manajemen namun belum sepenuhnya dapat mendorong penerapan inovasi terbuka di dalam perusahaan. Demikian juga mereka telah mengalami ketidakpastian lingkungan, tekanan daya saing dan memiliki kesigapan dari rekan bisnisnya namun hal tersebut tidak serta merta dapat mendorong penerapan inovasi terbuka di dalam perusahaan. Serta perusahaan sudah mendukung komunikasi, system manajemen database, system kolaboratif, kolaborasi budaya organisasi dan partisipasi manajemen namun tidak sepenuhnya dapat mendorong terciptanya kinerja inovasi di dalam perusahaan.

Perusahaan yang di teliti juga memperlihatkan hasil yang sesuai dengan dugaan penelitian antara lain, perusahaan startup telah menerapkan keinovasian, pengambilan resiko dan keproaktifan dalam internal perusahaan terhadap permintaan pasar di mana hal tersebut mampu mendorong perusahaan untuk menerapkan inovasi terbuka. Perusahaan juga telah mengalami ketidakpastian lingkungan, tekanan daya saing dan memiliki kesigapan dari rekan bisnisnya di mana hal tersebut mampu mendorong terciptanya kinerja inovasi di dalam perusahaan. Mereka telah menerapkan keinovasian, pengambilan resiko dan keproaktifan dalam internal perusahaan terhadap permintaan pasar di mana hal tersebut mampu mendorong perusahaan untuk menciptakan kinerja inovasi. Terlebih lagi perusahaan startup telah memiliki modal ventura dari internal perusahaan, menerapkan lisensi kekayaan intelektual dan keterlibatan karyawan yang tinggi dalam operasional dan keputusan perusahaan di mana hal tersebut mampu menciptakan kinerja inovasi dalam perusahaan.

\section{Saran}

Penelitian selanjutnya sebaiknya melakukan studi pada UMKM atau bidang usaha lain yang melibatkan lebih banyak sumber daya manusia, karena dengan banyaknya sumber daya manusia yang terlibat dalam bidang usaha dapat diteliti budaya organisasinya. Responden penelitian sangatlah penting bagi suatu penelitian, dalam penelitian ini mengambil sampel dari para technopreneur khususnya startup company yang sebagian besar umur perusahaannya kurang dari 1 tahun. 
Dengan umur perusahaan yang masih singkat karakteristik organisasi belum terbentuk, sehingga menyebabkan hipotesis yang berkaitan dengan karakteristik organisasi menjadi tertolak. Maka penelitian selanjutnya diharapkan mempertimbangkan faktor usia perusahaan.

\section{DAFTAR PUSTAKA}

Abulrub, Abdul-Hadi G. and Junbae Lee (2012), "Open innovation management: challenges and prospects", Procedia - Social and Behavioral Sciences 41, pp.130 - 138

Andrea Stucki And Matthias Finger (2009), "Open Innovation As An Option For Reacting To Reform And Crisis: What Factors Influence The Adoption Of Open Innovation?", Pp. 1-7

APEC: Eminent Persons Group (1994) Achieving the APEC vision: Free and Open Trade in The Asia Pacific, Singapore: Asia Pacific Economic Cooperation. Agustus

Bardon, Natalia Irena (2012), "Regional Development in the Context of an Innovation Process", Working Papers Firms and Region, No. R5/2012, Fraunhofer Institute for Systems and Innovation Research ISI, pp.1-26

BPPT, (2010). "Naskah Akademis Kebijakan Pengembangan Technopreneurship." Mimeo, Pusat Pengkajian Kebijakan Peningkatan Daya Saing, Jakarta.

Chesbrough, H.W., (2003). Open Innovation: The New Imperative for Creating and Profiting from Technology. Harvard Business School Press, Boston.

Coraş, Eliza Laura and Adrian Dumitru Tanţău (2013), "A Risk Mitigation Model In Sme's Open Innovation Projects", Management \& Marketing Challenges For The Knowledge Society, Vol. 8, No. 2, pp. 303-328

Covin, J. P. \& Lumpkin, G. T. (2011) "Entrepreneurial Orientation Theory and Research: Reflections on a Needed Construct". Entrpreneurship Theory and Practice. 35 (5), 855-872 de Vrande, Vareska Van, Jeroen P.J.De Jong, Wim Vanhaverbeke, Maurice De Rochemont (2009), "Open Innovation In Smes: Trends, Motives And Management Challenges". Technovation 29, pp. 423-437

Drucker, Peter F (1985), "Innovation and Entrepreneurship: Practice and Principles", New York: Harper \& Row

Fimm, John Martin (2000), “Innovation Strategies in Australian Local Government", Melbourne, Australian Housing and Urban Research Institute

Frishamman J and Horte S.A (2005), "Managing external information in manufacturing firms: the impact of innovation performance"., The Journal of Product Innovation Management 22 (3) pp. 251-266

Gassmann, O., Enkel, E., (2004). Towards a Theory of Open Innovation: Three Core Process Archetypes. In: Paper presented at R\&D Management Conference, Lisbon.

Gil, Andres Barge (2011), "Open Strategies And Innovation Performance", MPRA Paper No. 31298, 5, pp.1-46

Herstad, Sverre J., Carter Bloch, Bernd Ebersberger, Els van de Velde (2008), "Open innovation and globalisation: Theory, evidence and implications", pp.1-96

Hisrch, R.D., Peters, M. P. \& Shepherd, D.A., (2008), Entrepreneurship, Singapore" McGraw-Hill Companies.

Huang, Fang (2011), “An Empirical Examination of The Applicability and Effectiveness of the Open Innovation Paradigm" Business School, The University of Adelaide, Doctor of Phylosophy

Hubeis, Musa, (2009), Prospek Usaha Kecil dalam Wadah Inkubator Bisnis. Bogor : Ghalia. Indonesia

Hung, Min (2007) "Influence of the environment on innovation performance of TQM", Total Quality Managment, 18 (7), pp. 715-730 
Inauen, Matthias and Andrea Schenker-Wicki (2011) "The impact of outside-in open innovation on innovation performance" European Journal of Innovation Management Vol. 14 No. 4

Ju, Pei-Hung, Deng-Neng Chen, Yu-Chun Yu, Hsiao-Lan Wei (2013), "Relationships among Open Innovation Processes, Entrepreneurial Orientation, and Organizational Performance of SMEs: The Moderating Role of Technological Turbulence", Business Information Processing Volume 158, pp 140-160

Katila R (2002), "New product search over time: past ideas in their prime?" Academy of Management Journal 45 (5) pp. 995-1010

Katila R. and Ahuja G (2002) "something old, something new: a longitudinal study of search behaviour and new product intriduction" Academy of Management Journal 45 (8) pp. 1183-1194

Kaya, Harun and Veysel Ağca (2012), "Entrepreneurial Orientation And Performance Of Turkish Manufacturing Fdi Firms: An Empirical Study" International Entrepreneurship and Management Journal, March 2012, Volume 8, Issue 1, pp 15-33

Krishnan, Sudeep K. \& Jain, Rekha (2013). "Processes, Strategies, and Performance Aspects of Open Innovation in Information Technology Sector - Insights from Experts," IIMA Working Papers WP2013-06-01, Indian Institute of Management Ahmedabad, Research and Publication Department

Lakovleva, Tatiana (2013), “Open Innovation at the Root of Entrepreneurial Strategy: A Case from the Norwegian Oil Industry", Technology Innovation Management Review, pp.17-22

Laursen, Keld and Ammon Salter (2006) “Open For Innovation: The Role Of Openness In Explaining Innovation Performance Among U.K. Manufacturing Firms", Strategic Management Journal Strat. Mgmt. J., 27: 131-150
Lee, S.M. \& Peterson, S. (2000). Culture, entrepreneurial orientation, and global competitiveness. Journal of World Business, 35: 401-416.

Lee, Sungjoo, Gwangman Park, Byungun Yoon, Jinwoo Park (2010), "Open innovation in SMEs-An intermediated network model", Research Policy 39, pp. 290-300

Li, Suhong (2002), “An Integrated model for supply chain management practice, performance and competitive advantage", doctoral dissertation. Toledo, OH: University of Toledo

Lumpkin , G. T. and Gregory G. Dess (1996), "Clarifying The Entrepreneurial Orientation Construct And Linking It To Performance", Academy Of Management Review, Vol. 21, No. 1, 135-172., Academy Of Management Review, Pp. 135-172

Lumpkin, G. T., \& Dess, G. G. (1996). Clarifying the entrepreneurial orientation construct and linking it to performance. Academy of Management Review, 21(1), 135-172

Machin, David and Campbell MJ (2005), Design of Studies for Medical Research. Chichester: John Wiley and Sons Ltd. Diakses secara online pada http://books.google.co.id/books?id=rr UIRz1Y9nEC\&pg=PA37\&hl=id\&sour ce $=$ gbs_toc_r\&cad $=4$, tanggal 12 Desember 2012.

Madhoushi, Mehrdad, Abdolrahim Sadati, Hamidreza Delavari, Mohsen Mehdivand and Ramin Mihandost (2011), "Entrepreneurial Orientation and Innovation Performance: The Mediating Role of Knowledge Management", Asian Journal of Business Management 3(4): 310-316

Mazzola, Erica, Manfredi Bruccoleri and Giovanni Perrone (2012) "The Effect Of Inbound, Outbound And Coupled Innovation On Performance”, International Journal Of Innovation Management, Vol. 16, No. 6

Mel, Suresh ; David McKenzie; Christopher Woodruff (2009), "Innovative Firms or 
Innovative Owners? Determinants of Innovation in Micro, Small, and Medium Enterprises", IZA DP No. 3962, pp. 1-35

Moreno, A. M., Casillas, J. C., (2008), "Entrepreneurial orientation and growth of SMEs: A causal model", Entrepreneurship Theory and Practice, 32, 507-528.

Nasution, Arman Hakim, Bustanul Arifin Noer dan Mokh. Suef, (2007). Enterpreneurship. Membangun Spirit Technopreneurship, Penerbit Andi, Yogyakarta

Parida, Vinit, Mats Westerberg, and Johan Frishammar (2012), "Inbound Open Innovation Activities in High-Tech SMEs: The Impact on Innovation Performance", Journal of Small Business Management 50(2), pp. 283309

Prajogo D.I and Ahmed P.K (2006), "Relationship between innovation stimulus, innovation capacity, and innovation performance", R\&D manegement 36 (5) pp.499-515

Prajogo D.I and Sohal A.S (2001) "The relationship between TQM practices, quality performance and innovation performance", International Journal Of Quality And Relaibility Management 20 (8) pp. 901-918

Singarimbun, Masri dan Effendi Sopyan. (1989). Metode Penelitian Survei. Jakarta: LP3ES

Sugiono (2012), Metode Penelitian Kualitatif, Kuantitatif dan R\&D,. Alfabeta, Bandung

Wang C.L and Ahmed P.K (2004), "The development and validation of the organisational innovativeness construct using confimatory factor analysis", European Journal of Innovation Management 7 (4) pp. 303-313

West MA. (2000). Reflexivity, revolution and innovation in work teams. In Advances in the interdisciplinary study of work teams: Product development team, Beyerlein MM, Johnson DA, Beyerlein
ST (eds). JAI Press: Stamford, Connecticut; 1-29

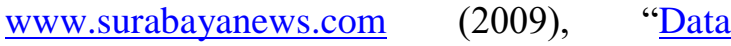
Statistik Menunjukkan Pengguna Internet Propinsi Jatim Meningkat" Pada [Diakses Secara Online 27 Juli 2012]

Pada

Http://Surabayawebs.Com/Index.Php/2 009/03/16/ 